\title{
Non-Traded Goods and Real Exchange Rate Volatility in a Two-Country DSGE Model
}

\author{
Nestor Azcona ${ }^{1}$ \\ ${ }^{1}$ Economics Division, Babson College, Wellesley, MA, USA \\ Correspondence: Nestor Azcona, Economics Division, Babson College, Babson Park, MA, 02457, USA. Tel: \\ 1-781-239-4533. E-mail: nazcona@babson.edu
}

Received: November 19, 2014

Accepted: December 5, 2014

Online Published: January 25, 2015

doi:10.5539/ijef.v7n2p36

URL: http://dx.doi.org/10.5539/ijef.v7n2p36

\begin{abstract}
This paper uses a two-country dynamic stochastic general equilibrium model (DSGE) to study how different characteristics of an economy, such as openness or price stickiness, affect the contribution of the relative price of non-traded goods to real exchange rate fluctuations. The model shows that changes in the relative price between traded and non-traded goods are the main channel through which productivity shocks are transmitted to the real exchange rate. Productivity and monetary shocks also affect the real exchange rate through changes in the international relative price of traded goods. The economy's characteristics have a significant effect on the transmission mechanism and the overall volatility of the real exchange rate in response to both types of shocks.
\end{abstract}

Keywords: non-traded goods, purchasing power parity, real exchange rate

\section{Introduction}

The real exchange rate measures the cost of goods and services in one country relative to the cost of goods and services in another. It is one of the most important factors determining a country's international competitiveness and trade balance, and is a key macroeconomic variable in the international transmission of business cycles. Real exchange rate fluctuations are known to be highly volatile and at the same time quite persistent, a phenomenon known as the purchasing power parity puzzle (Rogoff, 1996). Traditionally, macroeconomic research has followed two alternative approaches to modeling real exchange rate movements. In some macroeconomic models purchasing power parity (PPP) holds for traded goods prices and real exchange rate fluctuations are the result of changes in the prices of non-traded goods relative to the prices of traded goods (e.g. Backus and Smith, 1993). (Note 1) In practice, for a variety of reasons, purchasing power parity for traded goods prices does not hold at all times. However this PPP-based approach should offer a good description of real exchange rate movements if PPP deviations are small or short-lived. In other macroeconomic models all goods are tradable but domestic and foreign goods are not perfect substitutes and can have different prices (e.g. Chari et al., 2002). In that case real exchange rate movements are caused by changes in the relative price between traded goods sold at home and abroad, which create deviations from purchasing power parity for traded goods prices. This approach is appropriate if those PPP deviations are large relative to changes in the relative price between traded and non-traded goods.

What type of model offers a better description of real exchange rate movements? Engel (1999) offered an answer by calculating which fraction of real exchange rate changes can be attributed to changes in the international relative price of traded goods and which fraction can be attributed to changes in each country's domestic relative price between traded and non-traded goods. His methodology consisted in decomposing the real exchange rate (RER) into two components, as in equation (1), where $S$ stands for the nominal exchange rate, $P$ and $P^{*}$ stand for the overall consumer price level at home and abroad, respectively, and $P^{T}$ and $P^{T^{*}}$ stand for the price of traded goods sold at home and abroad, respectively. $R E R^{T}$ is the relative price between traded goods sold at home and those sold abroad. It equals one when purchasing power parity holds for traded goods prices. $R E R^{N}$ is a function of the domestic relative price between traded and non-traded goods in each country (Note 2).

$$
R E R_{t} \equiv \frac{S_{t} \times P_{t}^{*}}{P_{t}}=\frac{S_{t} \times P_{t}^{T^{*}}}{P_{t}^{T}} \times \frac{P_{t}^{*} / P_{t}^{T^{*}}}{P_{t} / P_{t}^{T}}=R E R_{t}^{T} \times R E R_{t}^{N}
$$

By taking logarithms and differences in equation (1) we obtain equation (2). The variance of the changes in the 
real exchange rate depends on the variances of the two components and a covariance term (equation (3)). If we allocate the covariance term proportionally to the variance of each component, the fraction of real exchange rate movements caused by changes in the international relative price of traded goods, $V D\left(\Delta r e r^{T}\right)$, is given by equation (4), and the fraction caused by changes in the domestic relative prices between traded and non-traded goods, $V D\left(\Delta r e r^{N}\right)$, is given by equation (5).

$$
\begin{gathered}
\Delta r e r_{t}=\Delta r e r_{t}^{T}+\Delta r e r_{t}^{N} \\
\operatorname{var}(\Delta r e r)=\operatorname{var}\left(\Delta r e r^{T}\right)+\operatorname{var}\left(\Delta r e r^{N}\right)+2 \operatorname{cov}\left(\Delta r e r^{T}, \Delta r e r^{N}\right) \\
V D\left(\Delta r e r_{t}^{T}\right)=\frac{\operatorname{var}\left(\Delta r e r_{t}^{T}\right)}{\operatorname{var}\left(\Delta r e r_{t}^{T}\right)+\operatorname{var}\left(\Delta r e r_{t}^{N}\right)} \\
V D\left(\Delta r e r_{t}^{N}\right)=\frac{\operatorname{var}\left(\Delta r e r_{t}^{N}\right)}{\operatorname{var}\left(\Delta r e r_{t}^{T}\right)+\operatorname{var}\left(\Delta r e r_{t}^{N}\right)}
\end{gathered}
$$

Engel (1999) found that, for the countries and periods he studied, almost all of the changes in the real exchange rate are caused by changes in the international relative price of traded goods. (Note 3) The fact that in the short run the nominal exchange rate is more volatile than prices could explain his results for short-term real exchange rate movements. But he found that his findings were also true for long-term changes of the real exchange rate. (Note 4) Similar real exchange rate variance decomposition studies followed and confirmed that changes in the international relative price of traded goods are the main driver of real exchange rate fluctuations (e.g. Chari et al., 2002). However some of these studies pointed out that the choice of the price indices used to measure traded goods prices has a significant effect on the results (Betts and Kehoe, 2006; Burstein et al., 2006) and showed that the domestic relative price between traded and non-traded goods also matters for real exchange rate movements. While some authors have used the consumer price index (CPI) for goods or the producer price index (PPI) as a proxy for traded goods prices, Burstein et al. (2006) suggest using import and export price indexes instead. Their argument is that the CPI for goods includes the cost of non-traded distribution and retail services, while import and export price indexes measure prices at the dock. Moreover, they measure the prices of goods actually traded rather than assuming that all goods are tradable and all services are non-tradable. They find that this approach increases the contribution of the relative price between traded and non-traded goods to more than fifty percent of the total variance of real exchange rate movements for some countries. Mendoza $(2000 ; 2005)$ also provides evidence that the relative price between traded and non-traded goods may be more important than what Engel's results suggested, at least under certain circumstances. He studies the U.S. Mexico real exchange rate and finds that the relative price between traded and non-traded goods is substantially more important during the managed exchange rate period than during the floating period. His findings support the view that changes in the international relative price of traded goods are more important than changes in the relative price of non-traded goods due to sticky prices and a very volatile nominal exchange rate. However sticky prices cannot explain why Engel's results don't change at long horizons, when prices become fully flexible.

The objective of this paper is to better understand the role of the relative price between traded and non-traded goods in real exchange rate fluctuations. The empirical studies discussed above indicate that, if measured properly, changes in that relative price may be an important driver of real exchange rate movements. However those studies have little to say about how the characteristics of an economy affect their relative importance vis-à-vis changes in the international relative price of traded goods. To that end I develop a two-country dynamic stochastic general equilibrium (DSGE) model and compare the overall real exchange rate volatility and variance decomposition under different assumptions about the economy. The DSGE model shows that the type of shock hitting the economy has a large influence on the relative importance of the two real exchange rate components. Monetary shocks are transmitted to the real exchange rate almost exclusively through changes in the international relative price of traded goods, while productivity shocks are transmitted to the real exchange rate through both channels. The effect of the characteristics of the economy on the level of real exchange rate volatility and on the contribution of the relative price of non-traded goods also depends on the type of shock. Therefore I conduct the analysis for each type shock separately. I first study how real exchange rate dynamics are affected by the level of international integration, determined in the model by the relative weight of the non-traded goods sector and the degree of preference for domestic traded goods. Since price stickiness is a common explanation for the importance of the international relative price of traded goods in the short run, I also compare the properties of the real exchange rate under different degrees of price stickiness. In addition I study the effect of the degree of risk aversion on the overall level of real exchange rate volatility and its variance 
decomposition.

Understanding the role of the relative price between traded and non-traded goods in real exchange rate fluctuations is an important task in macroeconomics. In fact, many studies have introduced non-traded goods into their models to better understand some empirical facts inconsistent with one-good open economy models. For example, Backus and Smith (1993) incorporate non-traded goods in a two-country model to study the small correlation of consumption across countries and the existence of large interest-rate differentials. Stockman and Tesar (1995) study the role of non-traded goods in explaining the behavior of consumption, investment, and the trade balance. Benigno and Thoenissen (2008) develop a model with non-traded goods and incomplete markets to explain the lack of correlation between the real exchange rate and relative consumption across countries. Corsetti et al. (2005) study Rogoff's PPP puzzle using a model in which productivity shocks in the traded and non-traded sectors are imperfectly correlated. They show that such a model is capable of matching the data if the economy is characterized by either a very high degree of risk aversion or a very low elasticity of substitution between domestic and foreign traded goods.

The paper proceeds as follows. Section 2 presents the theoretical model. In Section 3 the model is simulated to study the behavior of the real exchange rate under different assumptions. Section 4 concludes.

\section{Two-Country DSGE Model}

This section presents a small-scale two-country dynamic stochastic general equilibrium (DSGE) model that will be used to analyze the effects of different key features of an economy on the level of real exchange rate volatility and the fraction of this volatility explained by changes in the relative price between traded and non-traded goods. In the model each country produces two types of goods: traded and non-traded. Goods produced in the Home economy are denoted by $H$ if they are tradable and by $N$ if they are non-tradable. Tradable goods produced in the Foreign country are denoted by $F$. Prices with an asterisk are denominated in Foreign currency. Quantities with an asterisk are consumed by the Foreign country. For example, $C^{F^{*}}$ denotes consumption of Foreign good $F$ by Foreign consumers, and $P^{H^{*}}$ denotes the foreign-currency price at which Home good $H$ is sold in the Foreign market. Since the Foreign country is a mirror image of the Home country, only the latter is described in this section.

\subsection{Households}

There is a group of identical households of mass one. They receive wages $(W)$ from perfectly competitive wholesale firms and profits $(P R)$ from monopolistically competitive retail firms. Each household supplies labor $(L)$ to both sectors (traded and non-traded). They have access to a complete set of internationally-traded contingent securities that pay one unit of domestic currency if a particular state $z_{t}$ is realized in period $t$. Their budget constraint given a history of states $z^{t}=\left(z_{0}, z_{1}, \ldots, z_{t}\right)$ is described by (6), where $C$ denotes consumption, $P$ is the price index for the consumption basket, $Q_{t}\left(z_{t+1} \mid z^{t}\right)$ denotes the price in state $z_{t}$ of a security that pays off if state $z_{t+1}$ is realized, and $D_{t}\left(z_{t+1} \mid z^{t}\right)$ denotes the quantity of such securities held at the end of period $t$. Households' preferences over consumption and labor are described by the utility function (7), where $\beta$ is the subjective discount factor and $\operatorname{prob}\left(z^{t}\right)$ is the probability of history $z^{t}$.

$$
\begin{gathered}
P_{t}\left(z^{t}\right) C_{t}\left(z^{t}\right)+\sum_{z_{t+1}}\left\{Q_{t}\left(z_{t+1} \mid z^{t}\right) D_{t}\left(z_{t+1}\right)\right\}=D_{t-1}\left(z^{t}\right)+W_{t}^{H}\left(z^{t}\right) L_{t}^{H}\left(z^{t}\right)+W_{t}^{N}\left(z^{t}\right) L_{t}^{N}\left(z^{t}\right)+P R_{t}^{H}\left(z^{t}\right)+P R_{t}^{N}\left(z^{t}\right) \\
U_{0}=\sum_{t=0}^{\infty} \beta^{t} \sum_{z^{t}} \operatorname{prob}\left(z^{t}\right)\left[(1-\sigma)^{-1} C_{t}\left(z^{t}\right)^{1-\sigma}-(1+\omega)^{-1} L_{t}^{H}\left(z^{t}\right)^{1+\omega}-(1+\omega)^{-1} L_{t}^{N}\left(z^{t}\right)^{1+\omega}\right]
\end{gathered}
$$

Households maximize the utility function (7) subject to the budget constraint (6). The first order conditions with respect to labor in each sector are given by equations (8) and (9).

$$
\begin{aligned}
& \left(W_{t}^{H}\left(z^{t}\right) / P_{t}\left(z^{t}\right)\right) C_{t}\left(z^{t}\right)^{-\sigma}=L_{t}^{H}\left(z^{t}\right)^{\omega} \\
& \left(W_{t}^{N}\left(z^{t}\right) / P_{t}\left(z^{t}\right)\right) C_{t}\left(z^{t}\right)^{-\sigma}=L_{t}^{N}\left(z^{t}\right)^{\omega}
\end{aligned}
$$

The first order conditions with respect to consumption and asset holdings imply equation (10), where $\operatorname{prob}\left(z_{t+1} \mid z^{t}\right)$ is the probability of state $z_{t+1}$ conditional on history $z^{t}$. Summing up across states we can obtain the conventional stochastic Euler equation (11). The gross return of a risk-less one-period nominal bond is determined by (12).

$$
\beta \operatorname{prob}\left(z_{t+1} \mid z^{t}\right)\left(C_{t+1}\left(z^{t+1}\right) / C_{t}\left(z^{t}\right)\right)^{-\sigma}\left(P_{t}\left(z^{t}\right) / P_{t+1}\left(z^{t+1}\right)\right)=Q_{t}\left(z_{t+1} \mid z^{t}\right)
$$




$$
\begin{gathered}
\beta\left(1+R_{t}\left(z^{t}\right)\right) \sum_{z_{t+1}} \operatorname{prob}\left(z_{t+1} \mid z^{t}\right)\left[\left(C_{t+1}\left(z^{t+1}\right) / C_{t}\left(z^{t}\right)\right)^{-\sigma}\left(P_{t}\left(z^{t}\right) / P_{t+1}\left(z^{t+1}\right)\right)\right]=1 \\
1+R_{t}\left(z^{t}\right)=1 / \sum_{z_{t+1}} Q_{t}\left(z_{t+1} \mid z^{t}\right)
\end{gathered}
$$

The foreign counterparts of equations (10) and (11) are equations (13) and (14), where $S$ is the nominal exchange rate. We can use (10) and (13) to obtain the typical risk-sharing condition (15) that links the real exchange rate to the relative consumption levels and a constant $\xi$ that depends upon initial conditions. In addition we can combine the Home and Foreign Euler equations (11) and (14) to obtain the interest parity condition linking the domestic and foreign interest rates.

$$
\begin{gathered}
\beta \operatorname{prob}\left(z_{t+1} \mid z^{t}\right)\left(C_{t+1}^{*}\left(z^{t+1}\right) / C_{t}^{*}\left(z^{t}\right)\right)^{-\sigma}\left(P_{t}^{*}\left(z^{t}\right) / P_{t+1}^{*}\left(z^{t+1}\right)\right)\left(S_{t}\left(z^{t}\right) / S_{t+1}\left(z^{t+1}\right)\right)=Q_{t}\left(z_{t+1} \mid z^{t}\right) \\
\beta\left(1+R_{t}^{*}\left(z^{t}\right)\right) \sum_{z_{t+1}} \operatorname{prob}\left(z_{t+1} \mid z^{t}\right)\left[\left(C_{t+1}^{*}\left(z^{t+1}\right) / C_{t}^{*}\left(z^{t}\right)\right)^{-\sigma}\left(\left(P_{t}^{*}\left(z^{t}\right) S_{t}\left(z^{t}\right)\right) /\left(P_{t+1}^{*}\left(z^{t+1}\right) S_{t+1}\left(z^{t+1}\right)\right)\right)\right]=1 \\
C_{t}\left(z^{t}\right)=\xi C_{t}^{*}\left(z^{t}\right)\left(\left(S_{t}\left(z^{t}\right) P_{t}^{*}\left(z^{t}\right)\right) / P_{t}\left(z^{t}\right)\right)^{1 / \sigma}
\end{gathered}
$$

\subsection{Consumption Baskets}

The consumption basket in the Home country includes non-traded goods $(N)$ and domestic $(H)$ and foreign $(F)$ traded goods. Consumers buy different varieties of each good, which are sold by monopolistically competitive retailers and indexed by $i \in[0,1]$. Preferences over the varieties of $\operatorname{good} j=H, F, N$ are described by the constant-elasticity-of-substitution (CES) aggregator (16), where $\varepsilon$ is the elasticity of substitution between varieties.

$$
C^{j}=\left[\int_{0}^{1}\left(C_{i}^{j}\right)^{(\varepsilon-1) / \varepsilon} d i\right]^{\varepsilon /(\varepsilon-1)}
$$

Preferences between baskets of Foreign and Home traded goods are described by equation (17), where $\varsigma$ denotes the elasticity of substitution between Foreign and Home traded goods and $\kappa$ measures the degree of preference bias towards domestic traded goods. Similarly, preferences between baskets of non-traded and traded goods are described by equation (18), where $\eta$ denotes the elasticity of substitution between traded and non-traded goods and $\gamma$ measures the degree of preference bias towards non-traded goods.

$$
\begin{aligned}
C^{T} & =\left[\kappa\left(C^{H}\right)^{(\varsigma-1) / \varsigma}+(1-\kappa)\left(C^{F}\right)^{(\varsigma-1) / \varsigma}\right]^{\varsigma /(\varsigma-1)} \\
C & =\left[\gamma\left(C^{N}\right)^{(\eta-1) / \eta}+(1-\gamma)\left(C^{T}\right)^{(\eta-1) / \eta}\right]^{\eta /(\eta-1)}
\end{aligned}
$$

Price indexes for these baskets of goods can be derived by calculating their unit cost. They are given by equations (19), (20) and (21).

$$
\begin{gathered}
P^{j}=\left[\int_{0}^{1}\left(P_{i}^{j}\right)^{1-\varepsilon} d i\right]^{1 /(1-\varepsilon)} \\
P^{T}=\left[\kappa\left(P^{H}\right)^{1-\varsigma}+(1-\kappa)\left(P^{F}\right)^{1-\varsigma}\right]^{1 /(1-\varsigma)} \\
P=\left[\gamma\left(P^{N}\right)^{1-\eta}+(1-\gamma)\left(P^{T}\right)^{1-\eta}\right]^{1 /(1-\eta)}
\end{gathered}
$$

These preferences imply the following domestic demand functions for each variety:

$$
\begin{gathered}
C_{i}^{H}=\kappa(1-\gamma)\left(P_{i}^{H} / P^{H}\right)^{-\varepsilon}\left(P^{H} / P^{T}\right)^{-\varsigma}\left(P^{T} / P\right)^{-\eta} C \\
C_{i}^{F}=(1-\kappa)(1-\gamma)\left(P_{i}^{F} / P^{F}\right)^{-\varepsilon}\left(P^{F} / P^{T}\right)^{-\varsigma}\left(P^{T} / P\right)^{-\eta} C \\
C_{i}^{N}=\gamma\left(P_{i}^{N} / P^{N}\right)^{-\varepsilon}\left(P^{N} / P\right)^{-\eta} C
\end{gathered}
$$

\subsection{Production}

Wholesale output for each good is produced by competitive firms using labor as the only input. In the steady state a fraction $\gamma$ of household labor is the dedicated to the production of non-traded goods and the rest to the production of traded goods. The production function in sector $j$ is given by (25), where $A$ denotes labor 
productivity.

$$
Y_{t}^{j}\left(z^{t}\right)=A_{t}^{j}\left(z^{t}\right) L_{t}^{j}\left(z^{t}\right)
$$

Monopolistically competitive retail firms purchase output from wholesale firms, differentiate it, and sell it with a mark-up. Retail prices are sticky as in Calvo (1983). In any given period the probability of a firm being able to adjust its price is $1-\theta$. Each period Home firms in the non-traded sector that are able to adjust their price will choose $\bar{P}_{i, t}^{N}\left(z^{t}\right)$ to maximize their expected discounted profits (26) subject to the demand function (27).

$$
\begin{gathered}
\sum_{\tau=0}^{\infty}(\beta \theta)^{\tau} \sum_{z^{t+\tau}} \operatorname{prob}\left(z^{t+\tau}\right)\left[\left(\frac{P_{t+\tau}\left(z^{t+\tau}\right) C_{t+\tau}\left(z^{t+\tau}\right)}{P_{t}\left(z^{t}\right) C_{t}\left(z^{t}\right)}\right)^{-\sigma}\left(\bar{P}_{i, t}^{N}\left(z^{t}\right)-\frac{W_{t+\tau}^{N}\left(z^{t+\tau}\right)}{A_{t+\tau}^{N}\left(z^{t+\tau}\right)}\right) C_{i, t+\tau}^{N}\left(z^{t+\tau}\right)\right] \\
C_{i, t+\tau}^{N}\left(z^{t+\tau}\right)=\gamma\left(\bar{P}_{i, t}^{N}\left(z^{t}\right) / P_{t+\tau}^{N}\left(z^{t+\tau}\right)\right)^{-\varepsilon}\left(P_{t+\tau}^{N}\left(z^{t+\tau}\right) / P_{t+\tau}\left(z^{t+\tau}\right)\right)^{-\eta} C_{t+\tau}\left(z^{t+\tau}\right)
\end{gathered}
$$

The optimal price $\bar{P}_{i, t}^{N}\left(z^{t}\right)$ must satisfy equation (28). Since all firms in the same sector face a similar problem, it must be that $\bar{P}_{i, t}^{N}\left(z^{t}\right)=\bar{P}_{t}^{N}\left(z^{t}\right)$ for all $i$. The presence of many firms implies that every period only a fraction 1- $\theta$ of firms will be able to adjust their prices. This implies that the evolution of the price index for non-traded goods is given by (29).

$$
\begin{gathered}
\sum_{\tau=0}^{\infty}(\beta \theta)^{\tau} \sum_{z^{t+\tau}} \operatorname{prob}\left(z^{t+\tau}\right)\left[\left(\frac{P_{t+\tau}\left(z^{t+\tau}\right) C_{t+\tau}\left(z^{t+\tau}\right)}{P_{t}\left(z^{t}\right) C_{t}\left(z^{t}\right)}\right)^{-\sigma}\left(\bar{P}_{i, t}^{N}\left(z^{t}\right)-\frac{\varepsilon}{(\varepsilon-1)} \frac{W_{t+\tau}^{N}\left(z^{t+\tau}\right)}{A_{t+\tau}^{N}\left(z^{t+\tau}\right)}\right) C_{i, t+\tau}^{N}\left(z^{t+\tau}\right)\right]=0 \\
P_{t}^{N}\left(z^{t}\right)=\left[\theta\left(P_{t-1}^{N}\left(z^{t-1}\right)\right)^{1-\varepsilon}+(1-\theta)\left(\bar{P}_{t}^{N}\left(z^{t}\right)\right)^{1-\varepsilon}\right]^{1 /(1-\varepsilon)}
\end{gathered}
$$

The log-linearization of (28) and (29) implies a New Keynesian Phillips curve for non-traded goods. The pricing problem for firms producing a traded good is similar, but in this case each firm chooses two prices, one for the Home market and one for the Foreign market. Each price is set in the local currency of the market where the good is sold. Home firms will separately choose $\bar{P}_{i, t}^{H}$ and $\bar{P}_{i, t}^{H^{*}}$ to maximize (30) and (31), respectively. Following similar steps we can derive the New Keynesian Phillips curves for domestic traded goods at home and abroad.

$$
\begin{gathered}
\sum_{\tau=0}^{\infty}(\beta \theta)^{\tau} \sum_{z^{t+\tau}} \operatorname{prob}\left(z^{t+\tau}\right)\left[\left(\frac{P_{t+\tau}\left(z^{t+\tau}\right) C_{t+\tau}\left(z^{t+\tau}\right)}{P_{t}\left(z^{t}\right) C_{t}\left(z^{t}\right)}\right)^{-\sigma}\left(\bar{P}_{i, t}^{H}\left(z^{t}\right)-\frac{W_{t+\tau}^{H}\left(z^{t+\tau}\right)}{A_{t+\tau}^{H}\left(z^{t+\tau}\right)}\right) C_{i, t+\tau}^{H}\left(z^{t+\tau}\right)\right] \\
\sum_{\tau=0}^{\infty}(\beta \theta)^{\tau} \sum_{z^{t+\tau}} \operatorname{prob}\left(z^{t+\tau}\right)\left[\left(\frac{P_{t+\tau}\left(z^{t+\tau}\right) C_{t+\tau}\left(z^{t+\tau}\right)}{P_{t}\left(z^{t}\right) C_{t}\left(z^{t}\right)}\right)^{-\sigma}\left(\bar{P}_{i, t}^{H^{*}}\left(z^{t}\right) S_{t+\tau}\left(z^{t+\tau}\right)-\frac{W_{t+\tau}^{H}\left(z^{t+\tau}\right)}{A_{t+\tau}^{H}\left(z^{t+\tau}\right)}\right) C_{i, t+\tau}^{H^{*}}\left(z^{t+\tau}\right)\right]
\end{gathered}
$$

Since prices are sticky in the currency of the country where they are sold, the law of one price may not hold for traded goods sold in both countries. Local prices can't immediately fully adjust to changes in the nominal exchange rate. That incomplete exchange-rate pass-through implies that exogenous shocks can create deviations from PPP for the baskets of traded goods sold in each country. Deviations from PPP can also arise even when the law of one price holds for individual goods if the baskets of traded goods at home and abroad are not identical.

\subsection{Monetary Policy}

The central bank chooses its policy instrument, the one-period nominal interest rate, based on the past interest rate, expected future inflation and the current output gap. The central bank's policy rule is described by (32), where $\bar{R}$ is the steady-state nominal interest rate (equal to the natural real interest rate plus the target inflation rate $\bar{\Pi}$ ), and $\delta$ determines the degree of interest-rate inertia. Exogenous i.i.d. monetary shocks $(v)$ are introduced as deviations of the interest rate from the central bank's target rate.

$$
R_{t}\left(z^{t}\right)=\delta R_{t-1}\left(z^{t-1}\right)+(1-\delta)\left[\bar{R}+\delta_{\pi} \sum_{z_{t+1}} \operatorname{prob}\left(z_{t+1} \mid z^{t}\right)\left(\Pi_{t+1}\left(z^{t+1}\right)-\bar{\Pi}\right)+\delta_{y} y_{t}\left(z^{t}\right)+v_{t}\left(z_{t}\right)\right]
$$

\section{Model Simulation}

\subsection{The Log-Linearized Model}

In order to simulate the model I first log-linearize it around its steady state. Percentage deviations from the 
steady state are denoted by lower-case letters. The Euler equation, interest-parity and risk-sharing conditions are given by equations (33), (34) and (35), respectively.

$$
\begin{gathered}
c_{t}=-\sigma^{-1}\left(r_{t}-E_{t} \pi_{t+1}\right)+E_{t} c_{t+1} \\
E_{t} \Delta r e r_{t+1}=r_{t}-E_{t} \pi_{t+1}-\left(r_{t}^{*}-E_{t} \pi_{t+1}^{*}\right) \\
c_{t}-c_{t}^{*}=\sigma^{-1} \operatorname{rer}_{t}
\end{gathered}
$$

The aggregate supply equations for goods sold in the Home country are given by equations (36), (37) and (38), where the lambdas depend on the model's parameters, rpn is the relative price between non-traded and traded goods, and $\mathrm{rer}^{F}$ is the ratio between the foreign price and the domestic price of the foreign traded good.

$$
\begin{gathered}
\pi_{t}^{N}=\frac{(1-\beta \theta)(1-\theta)}{\theta}\left[(\sigma+\omega) c_{t}-(1+\omega)(1-\gamma) r p n_{t}-(1+\omega) a_{t}^{N}\right]+\beta E_{t} \pi_{t+1}^{N} \\
\pi_{t}^{H}=\lambda_{A} c_{t}+\lambda_{B} c_{t}^{*}+\lambda_{C} t_{t} t_{t}-\lambda_{D} t_{t} t_{t}^{*}+\lambda_{E} r p n_{t}+\lambda_{F} r p n_{t}^{*}-\lambda_{G} a_{t}^{H}+\beta E_{t} \pi_{t+1}^{H} \\
\pi_{t}^{F}=\lambda_{A} c_{t}^{*}+\lambda_{B} c_{t}+\lambda_{C} t_{t}^{*} t_{t}^{*}-\lambda_{D} \text { tot }_{t}+\lambda_{E} r p n_{t}^{*}+\lambda_{F} r p n_{t}-\lambda_{G} a_{t}^{F}+\lambda_{H} r e r_{t}^{F}+\beta E_{t} \pi_{t+1}^{F}
\end{gathered}
$$

The productivity levels in each sector follow the autoregressive process (39), where $\chi^{j}$ are sectorial productivity shocks that may be correlated across sectors.

$$
a_{t}^{j}=\rho^{j} a_{t-1}^{j}+\chi_{t}^{j}
$$

Finally, the interest-rate rule is given by equation (40).

$$
r_{t}=\delta r_{t-1}+(1-\delta)\left(\delta_{\pi} E_{t} \pi_{t+1}+\delta_{y} y_{t}+v_{t}\right)
$$

\subsection{Parameterization}

The baseline parameter values used in the model are presented in Table 1. The share of non-traded goods in the overall consumption basket is set to match the sum of the shares of personal consumption expenditures on services (43\%), construction (9\%) and government spending (15\%) in the U.S. final domestic demand during the period 1980-2012. The share of home goods in the traded goods basket is chosen so that the model's imports/GDP ratio in the steady state matches the share of foreign value added in the U.S. final domestic demand $(12 \%)$, which is obtained from the OECD's Trade in Value Added database. The rest of parameters are standard or within the usual range used in the international macroeconomics literature. The parameters that depend on frequency are chosen to match quarterly frequency. The subjective discount factor is set at the conventional value of 0.99 . The coefficient of relative risk aversion is set to 2 , which is within the rage found in the macroeconomics literature. The parameter $\omega$ is set to 2, which implies an elasticity of labor supply equal to $1 / 2$. As in Stockman and Tesar (1995), the elasticity of substitution between traded and non-traded goods is 0.44 . The elasticity of substitution between domestic and foreign traded goods is 1.5, as suggested by Backus et al. (1994). The probability that a firm is not able to adjust its price in a given quarter is 0.75 , which implies that, on average, firms change their prices every four quarters. The monetary policy rule parameters are also within the range of commonly used values: 0.75 for the lagged interest rate, 1.5 for deviations of inflation from its target and 0.125 for the output gap.

Table 1. Model parameters

\begin{tabular}{clc}
\hline$\beta$ & Subjective discount factor & 0.99 \\
$\sigma$ & Coefficient of relative risk aversion & 2 \\
$\omega$ & Inverse of the elasticity of labor supply & 2 \\
$\gamma$ & Share of non-traded goods in consumption & 0.67 \\
$\kappa$ & Share of home goods in traded goods spending & 0.64 \\
$\eta$ & Elasticity of substitution between traded and non-traded goods & 0.44 \\
$\varsigma$ & Elasticity of substitution between home and foreign traded goods & 1.5 \\
$\theta$ & Calvo probability of no price adjustment & 0.75 \\
$\delta$ & Interest-rate smoothing & 0.75 \\
$\delta_{\pi}$ & Inflation target coefficient & 1.5 \\
$\delta_{y}$ & Output gap coefficient & 0.125 \\
\hline
\end{tabular}


Estimates of the variances, covariances and autocorrelations of the sectorial productivity shocks are obtained from Stockman and Tesar (1995). They estimate these parameters using data from the United States and four other OECD countries. The autocorrelation coefficients of the productivity disturbances in the traded and non-traded goods sectors are 0.154 and 0.632 , respectively. Their estimated correlation is $46 \%$. The variance-covariance matrix for the productivity shocks is given by (41).

$$
\operatorname{var}\left[\begin{array}{l}
\chi_{t}^{H} \\
\chi_{t}^{N} \\
\chi_{t}^{F} \\
\chi_{t}^{M}
\end{array}\right]=\left[\begin{array}{llll}
3.62 & 1.23 & 1.21 & 0.51 \\
1.23 & 1.99 & 0.51 & 0.27 \\
1.21 & 0.51 & 3.62 & 1.23 \\
0.51 & 0.27 & 1.23 & 1.99
\end{array}\right]
$$

The monetary shocks are assumed to be uncorrelated. Their standard deviation is set at $1 \%$ so that the benchmark model's ratio of real exchange rate volatility to output volatility equals three, as in U.S. quarterly data during the period 1985-2013. (Note 5) The persistence of the monetary shocks is determined by the persistence of the monetary policy rules.

\subsection{Simulation Results}

Table 2 shows some statistics for the benchmark model, which includes both productivity and monetary shocks, and for models in which only one type of shock is included. While the benchmark model matches the volatility of the real exchange rate relative to output found in U.S. quarterly data (2.98 vs. 3.06), the model exhibits less real exchange rate persistence $(0.62 \mathrm{vs}$. 0.79$)$. If only productivity shocks were present the level of real exchange rate volatility (relative to output) would be lower than in the benchmark model, but the real exchange rate would be much more persistent. By contrast, monetary shocks alone would generate more real exchange rate volatility, but with less persistence. In all models, despite the existence of complete financial markets allowing risk-sharing across countries, domestic consumption is highly correlated with domestic output. That is consistent with the output-consumption correlations calculated by Stockman and Tesar (1995) for several OECD economies, which range from 0.82 to 0.95 . Foreign and domestic consumption are correlated (although not much) in the model with only productivity shocks. However they are uncorrelated when monetary shocks are included. That is at odds with the data. Stockman and Tesar find cross-country consumption correlations ranging from 0.35 to 0.71 . This discrepancy may be caused by the fact that the only demand shock in the model is a monetary shock, which is assumed to be independent across countries.

Table 2. Model statistics

\begin{tabular}{lccc}
\hline & Benchmark & Productivity & Monetary \\
& Model & Shocks & Shocks \\
\hline Std. Dev. (rer) / Std. Dev. (y) & 2.98 & 1.91 & 3.40 \\
Autocorrelation (rer) & 0.62 & 0.91 & 0.57 \\
Correlation $(y, c)$ & $95 \%$ & $91 \%$ & $98 \%$ \\
Correlation $\left(c, c^{*}\right)$ & $1 \%$ & $29 \%$ & $-6 \%$ \\
RER Variance Decomposition, $\mathrm{VD}\left(\mathrm{\Delta rer}^{T}\right)-\mathrm{VD}\left(\mathrm{Arer}^{N}\right)$ & $90 \%-10 \%$ & $31 \%-69 \%$ & $100 \%-0 \%$ \\
RER Variance Decomposition, $\mathrm{VD}\left(\mathrm{rer}^{T}\right)-\mathrm{VD}\left(\mathrm{rer}^{N}\right)$ & $67 \%-33 \%$ & $23 \%-77 \%$ & $98 \%-2 \%$ \\
\hline
\end{tabular}

The second to last row of Table 2 indicates the fraction of real exchange rate quarterly movements explained by changes in the international relative price of traded goods and the fraction explained by changes in the domestic relative prices between traded and non-traded goods in each country. These are the statistics described earlier in equations (4) and (5), and correspond to the typical real exchange rate variance decomposition calculated in empirical studies. Chari et al. (2002) find that changes in the international relative price of traded goods explain $98 \%$ of U.S. real exchange rate quarterly movements. Engel (1999) finds similar results for monthly data. Burstein at al. (2006) use a different methodology and reduce that estimate to $39 \%$. In the benchmark model changes in the international relative price of traded goods explain $90 \%$ of real exchange rate quarterly movements (Note 6).

The last row provides the fraction of real exchange rate deviations from its steady state explained by deviations from purchasing power parity for traded goods prices (which holds in the model's steady state) and the fraction explained by deviations of the domestic relative prices between traded and non-traded goods from their respective steady-state values. Although related, there is an important difference between the two real exchange 
rate variance decomposition measures reported in Table 2. The first one describes the reasons behind real exchange rate movements, while the second one indicates the reasons for its persistence away from its steady-state value. In the benchmark model there is a significant difference between the two measures: while movements in the international relative price of traded goods cause $90 \%$ of the quarterly changes of the real exchange rate, many of these movements offset each other, so that deviations from purchasing power parity for traded goods prices explain only two thirds of the deviations of the real exchange rate from its long-run trend. The variance decomposition of the real exchange rate (both for quarterly changes and for steady-state deviations) significantly depends on the type of shocks affecting the economy. In the case of monetary shocks practically all real exchange rate movements are the result of changes in the international relative prices of traded goods. In the case of productivity shocks most of the real exchange rate changes are explained by changes in the relative price between traded and non-traded goods, but changes in the international relative price of traded goods are also important.

Those differences between shocks are also evident in the impulse-response functions in Figure 1. They show the responses of the real exchange rate (solid line), $\operatorname{rer}^{N}$ (short dash) and $\operatorname{rer}^{T}$ (long dash) to one-standard-deviation-sized shocks over the following twelve quarters. (Note 7) Figure 1(d) shows that a monetary shock (defined as an exogenous increase in the domestic interest rate) appreciates the real exchange rate. (Note 8) Since the interest-rate differential causes a sharp appreciation of the nominal exchange rate, the real appreciation is almost exclusively explained by domestic traded goods becoming more expensive than foreign traded goods. The impact on the relative price between traded and non-traded goods is relatively small. As a result, changes in $\mathrm{rer}^{T}$ explain about $100 \%$ of changes in the real exchange rate caused by monetary shocks, as shown in Table 2.

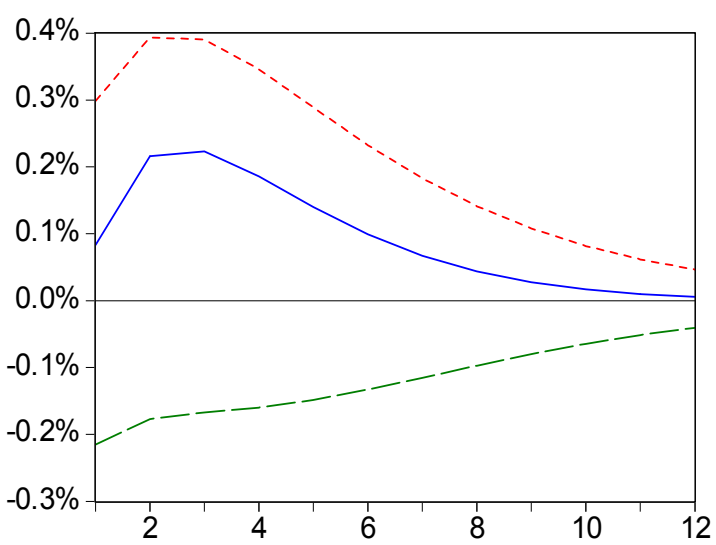

(a) Non-Traded Sector Productivity Shock

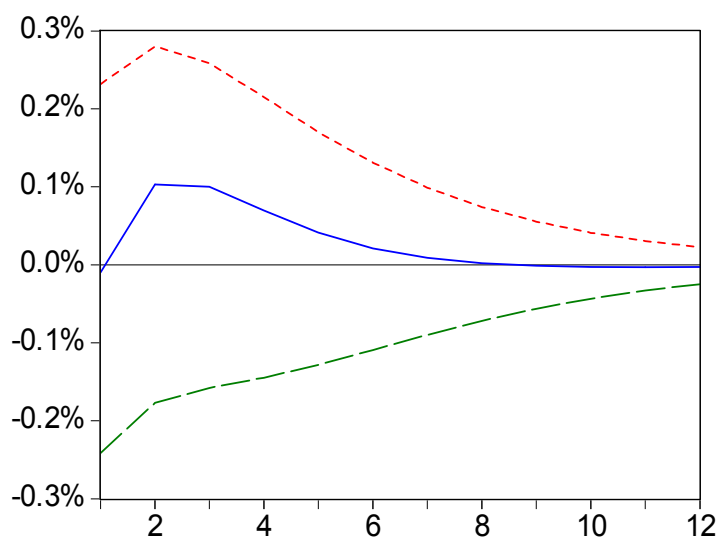

(c) Economy-wide Productivity Shock

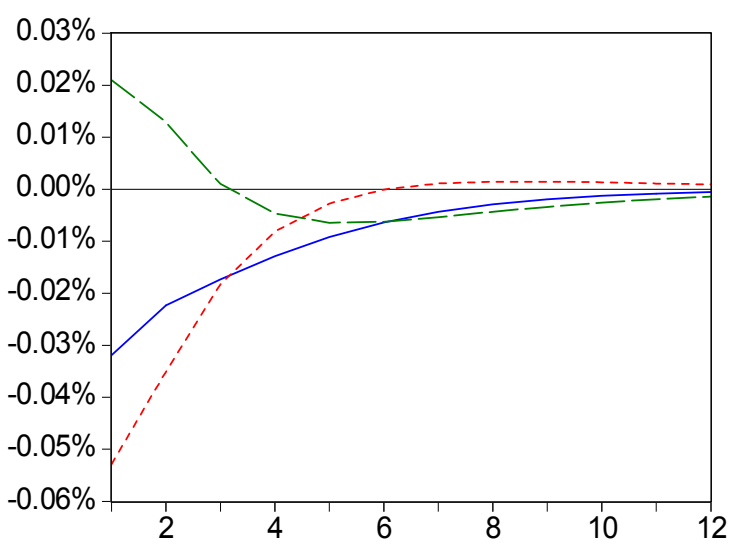

(b) Traded Sector Productivity Shock

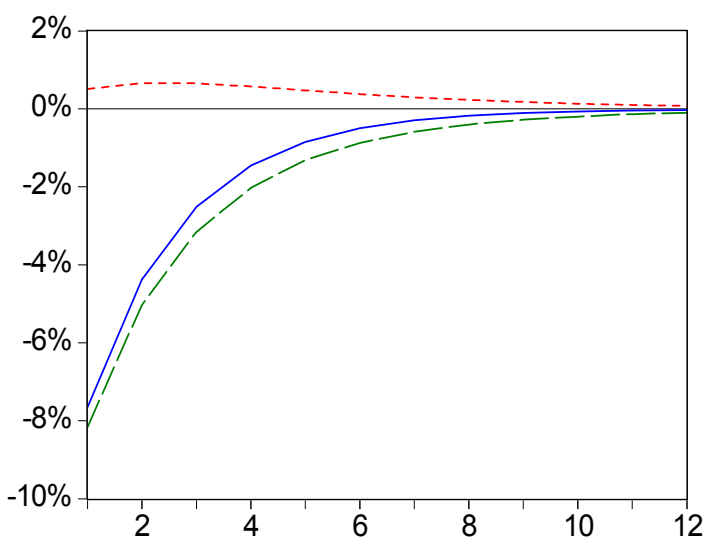

(d) Monetary Shock

Figure 1. Impulse-response functions of the real exchange rate and its components 
Sector-specific productivity shocks reduce the price of the good produced by that sector. They also create an interest-rate differential, but in this case it is caused by the response of the central banks to economic conditions. Figures 1(a) and 1(b) show that a productivity shock's impact on the real exchange rate and its components varies dramatically by sector. A productivity shock in the non-traded sector reduces the absolute and relative price of non-traded goods, which depreciates $\mathrm{rer}^{N}$. The nominal appreciation makes domestic traded goods more expensive relative to foreign traded goods. Since most traded goods sold at home are domestic, that causes a short-term deviation from purchasing power parity for traded goods prices ( $\mathrm{er}^{T}{ }^{T}$ appreciates). Even though traded goods become more expensive at home than abroad, the fall in the price of non-traded goods causes the real exchange rate to depreciate.

By contrast, a productivity shock in the traded goods sector causes a real appreciation, although relatively small. This may be surprising, since the productivity shock makes domestic traded goods cheaper. However the increase in output makes the central bank increase the domestic interest rate. The resulting nominal appreciation more than offsets the effect of lower prices for domestic traded goods on the overall price level. It's important to notice that in the previous case there is also a nominal appreciation. In that case the real exchange rate depreciates because non-traded goods prices have a larger weight on the overall price index. Productivity shocks in the traded goods sector also cause diverging responses of the two real exchange rate components, but in the opposite direction. Due to "home bias" $(\kappa>0.5)$, the fall in domestic traded goods prices has a bigger impact on the domestic traded goods basket than on the foreign traded goods basket. As a result rer $^{T}$ depreciates. Since domestic traded goods prices fall and the nominal appreciation makes imports cheaper, non-traded goods become relatively more expensive than traded goods and $\mathrm{rer}^{N}$ appreciates.

Figure 1(c) shows that, when productivity shocks affect both sectors equally, the responses of the real exchange rate and its components are more similar to those corresponding to shocks to the non-traded goods sector than to those corresponding to shocks to the traded goods sector. The reason is that non-traded goods represent a larger fraction of GDP than traded goods $(\gamma=0.67)$.

To better understand the role of non-traded goods in real exchange rate fluctuations, I simulate the model under different assumptions about the characteristics of the economy. In each case I calculate the volatility of the real exchange rate (relative to output) and its variance decomposition. Since Table 2 indicates that the role of non-traded goods depends on the type of shock, these simulations are made separately for productivity shocks (Figure 2) and for monetary shocks (Figure 3). The solid line corresponds to real exchange rate volatility (right scale), and the other two lines correspond to the fraction of real exchange rate movements explained by changes in the relative price between traded and non-traded goods, both for percentage deviations from its steady state $\left(V D\left(\mathrm{rer}^{N}\right)\right.$, short dash, left scale) and its quarterly changes $\left(V D\left(\Delta \mathrm{rer}^{N}\right)\right.$, long dash, left scale).

\subsection{Real Exchange Volatility and the Role of Non-Traded Goods in the Case of Productivity Shocks}

The fraction of non-traded goods in the consumption basket $(\gamma)$ affects the degree of openness in an economy (exports and imports over GDP) and the correlation between its domestic output and its domestic consumption. Figure 2(a) shows that, as the fraction of non-traded goods increases, the real exchange rate becomes more volatile. Other things equal, productivity shocks generate four times more real exchange rate volatility in an economy where $90 \%$ of its consumption is made of non-traded goods than in one in which non-traded goods represent only $10 \%$. As discussed in the previous section, productivity shocks in the non-traded sector cause more real exchange rate volatility than shocks in the traded sector. Therefore an increase in the weight of the non-traded goods sector will cause an increase in the volatility of the real exchange rate. This increase in overall real exchange rate volatility can be attributed to a significant increase in the volatility of $\mathrm{rer}^{N}$. The volatility of $\mathrm{rer}^{T}$ also increases, but not as much. As a result, the fraction of real exchange rate movements caused by changes in the relative price of non-traded goods increases dramatically, from as little as $16 \%$ to as much as $72 \%$. The large effect of $\gamma$ on $\mathrm{rer}^{N}$ can be explained by equation (42), which links the variance of the relative price of non-traded goods to that of the real exchange rate. A higher fraction of non-traded goods does not significantly increase the volatility of the relative price of non-traded goods. However, it significantly increases the effect that changes in the relative price of non-traded goods have on the real exchange rate. For example, holding the price of traded goods constant, a $1 \%$ increase in the price of domestic non-traded goods will increase the relative price of non-traded goods by $1 \%$ regardless of the weight on non-traded goods in the economy. But as that weight increases the effect on the overall domestic price level will be larger, causing a larger difference between the domestic and foreign price levels.

$$
\operatorname{var}\left(r e r_{t}^{N}\right)=\gamma^{2} \operatorname{var}\left(p_{t}^{N} / p_{t}^{T}\right)
$$

The weight of domestic goods in the basket of traded goods $(\kappa)$ is another factor determining the degree of 
openness in the economy. A value of $\kappa$ above 0.5 represents a preference bias toward the country's own goods. (Note 9) Figure 2(b) shows that an increase the degree of "home bias" has a non-monotonic, U-shaped effect on the volatility of the real exchange rate, but it has a strictly increasing effect for the more relevant range in which the economy consumes more domestic traded goods than foreign traded goods $(\kappa>0.5)$. This implies that productivity shocks generate more real exchange rate volatility in economies that don't trade a lot with each other and have very different consumption baskets of tradable goods than in more interdependent economies. This result cannot be attributed to either component of the real exchange rate. A closer look reveals that the volatility of both components actually falls as home bias rises, but the overall variance of the real exchange rate increases because their covariance becomes less negative. We know from Figure 1(b) that in response to a positive productivity shock in the domestic traded goods sector the nominal exchange rate appreciates and creates a deviation from PPP for traded goods prices. That PPP deviation is partially offset by the fall in the price of the traded goods basket at home $\left(P^{T}\right)$. As home bias increases, a change in the price of domestic traded goods $\left(P^{H}\right)$ has a larger impact on the price of traded goods at home $\left(P^{T}\right)$, and that diminishes the response of $\operatorname{rer}^{T}$ to those productivity shocks. Productivity shocks in both sectors are positively correlated. When both $P^{N}$ and $P^{H}$ rise, the effect on $P^{N} / P^{T}$ is smaller if $\kappa$ is larger and $P^{H}$ has a larger impact on $P^{T}$. That contributes to reducing the volatility of $\mathrm{rer}^{N}$. Figure 2(b) shows that, in general, as $\kappa$ increases the variance of $\mathrm{rer}^{T}$ falls faster than the variance of $\mathrm{rer}^{N}$. This implies that in less open economies a larger fraction of real exchange rate movements are caused by changes in the relative price of non-traded goods.

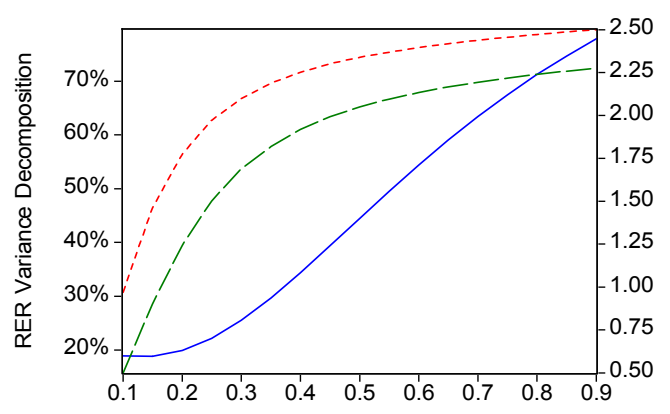

(a) Steady-State Fraction of Non-Traded Goods

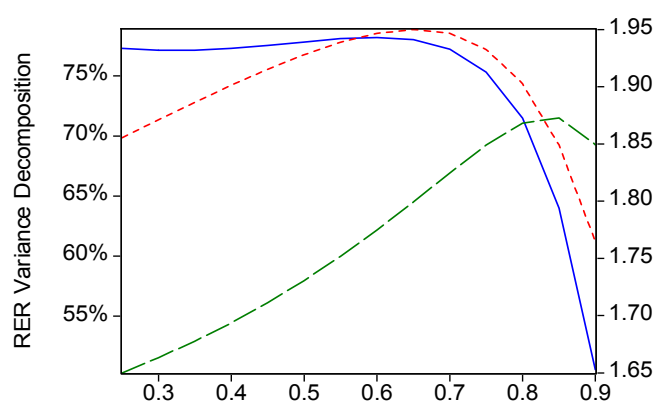

(c) Price Stickiness

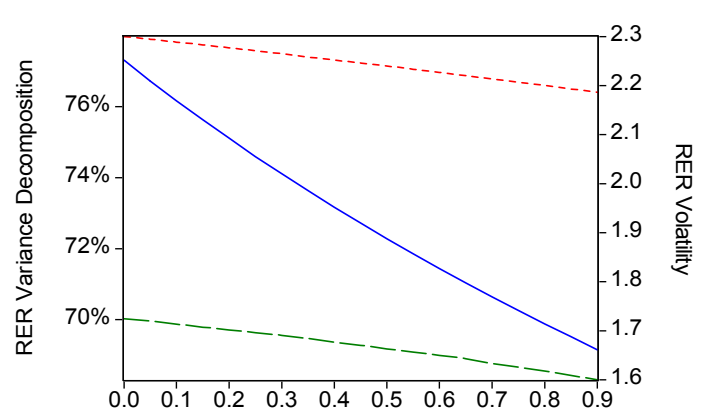

(e) Correlation Betw een Traded and Non-Traded Sector Shocks

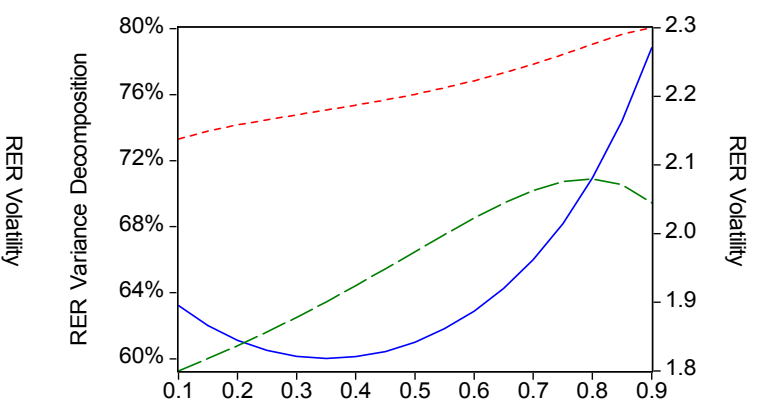

(b) Home Bias for Traded Goods

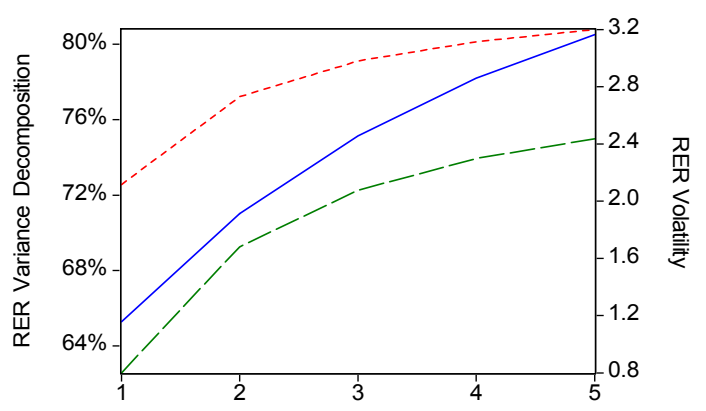

(d) Coefficient of Relative Risk Aversion

Figure 2. Real exchange rate volatility and variance decomposition (productivity shocks) 
Price stickiness (measured by $\theta$ ) refers to the frequency with which firms change their prices to adjust to current and expected economic conditions. As firms keep prices unchanged for longer periods the effect of productivity shocks on prices becomes smaller. That reduces the response of the relative price between traded and non-traded goods but also that of the relative price between domestic and foreign traded goods. At low levels of price stickiness the volatility of $\mathrm{rer}^{T}$ falls faster and $\mathrm{rer}^{N}$ gains importance, but the opposite happens at high levels of price stickiness, creating the inverted U-shaped variance decompositions in Figure 2(c). Price stickiness also reduces the overall volatility of the real exchange rate. But since price stickiness reduces the effect of supply shocks on output, the volatility of the real exchange rate relative to output does not decrease monotonically. It remains more or less unchanged for low degrees of price stickiness and it falls very rapidly when prices adjust very infrequently.

It is well-known that the coefficient of relative risk-aversion $(\sigma)$ has a significant effect on the overall volatility of the real exchange rate (Chari et al., 2002; Corsetti et al., 2005). The coefficient of relative risk aversion is equal to the inverse of the elasticity of inter-temporal substitution, and it links the volatility of the real exchange rate to that of the domestic-foreign consumption ratio. This is clear by taking the standard deviation on both sides of equation (35), which results in equation (43). In the case of productivity shocks, when the coefficient of relative risk-aversion rises from one to five the volatility of the real exchange rate relative to output rises from 1.2 to 3.2. Both the volatility of $\mathrm{rer}^{T}$ and $\mathrm{rer}^{N}$ increase, but the effect on $\mathrm{rer}^{N}$ is stronger.

$$
s d\left(c_{t}-c_{t}^{*}\right)=\sigma^{-1} s d\left(\text { rer }_{t}\right)
$$

The last parameter examined is the correlation between productivity shocks in the traded goods sector and productivity shocks in the non-traded goods sector. In the benchmark model this correlation is $46 \%$, as estimated by Stockman and Tesar (1995). When productivity shocks are sector-specific and not perfectly correlated, they change the cost of non-traded goods relative to domestically-produced traded goods, adding an additional source of movements in the relative price between traded and non-traded goods. Figure 2(e) shows that when the cross-sector correlation decreases from $90 \%$ to $0 \%$, the volatility of the real exchange rate relative to output rises from 1.7 to 2.3. However, the relative importance of changes in the relative price between traded and non-traded goods only increases by $2 \%$, from $68 \%$ to $70 \%$, since the volatility of movements in the international relative price of traded goods also rises.

\subsection{Real Exchange Volatility and the Role of Non-Traded Goods in the Case of Monetary Shocks}

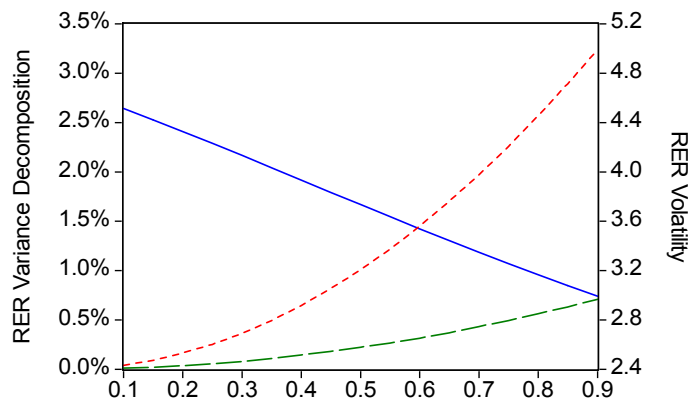

(a) Steady-State Fraction of Non-Traded Goods

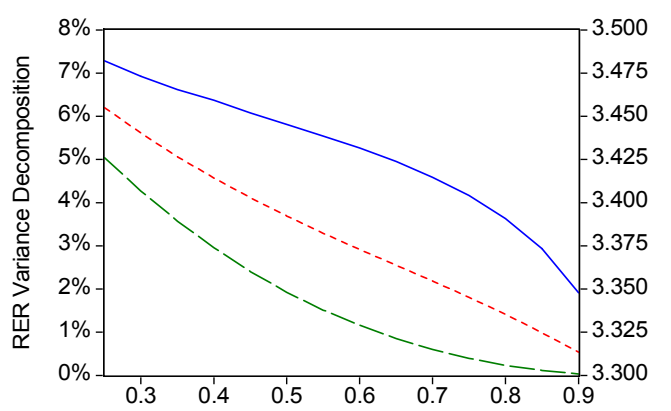

(c) Price Stickiness

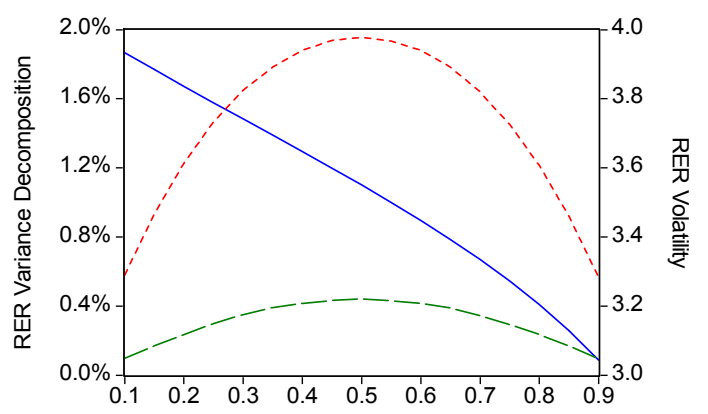

(b) Home Bias for Traded Goods

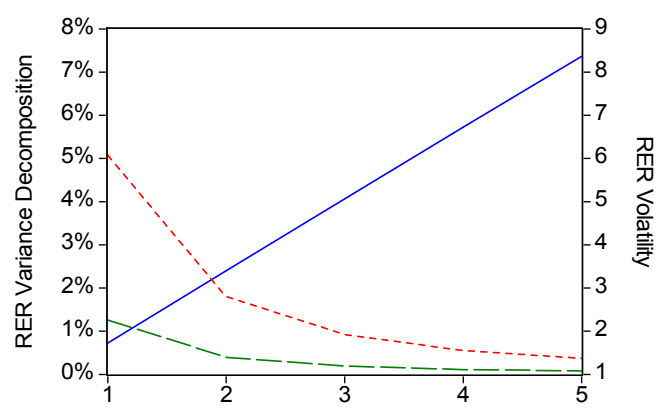

(d) Coefficient of Relaltive Risk Aversion

Figure 3. Real exchange rate volatility and variance decomposition (monetary shocks) 
Figure 3 shows the effect of certain model parameters on the level of real exchange rate volatility relative to output and on the two types of real exchange rate variance decompositions when the model is exclusively driven by monetary shocks. In this case, since monetary shocks do not have a direct impact on the relative price of non-traded goods, movements in that relative price only explain a very small fraction of overall real exchange rate movements. Thus the effect of the model parameters on overall real exchange volatility mainly depends on the effect that those parameters have on the international relative price of traded goods.

Unlike in the case of productivity shocks, monetary shocks have a smaller impact on real exchange rate fluctuations when the non-traded sector represents a larger fraction of the economy (Figure 3(a)). When the weight of non-traded goods rises from $10 \%$ to $90 \%$ of the economy, the volatility of the real exchange rate caused by monetary shocks falls from 4.4 to 3 times the volatility of output. An exogenous interest rate increase appreciates the nominal exchange rate and creates deviations from PPP for traded goods prices. The interest rate increase also curbs domestic consumption and reduces prices of goods consumed at home, which partially offsets the nominal appreciation. If non-traded goods represent a larger fraction of the consumption basket then the fall in the home price level is larger, and deviations from PPP are more moderate. That also contributes to increase the relative importance of movements in the relative price of non-traded goods, although moderately.

When the economy becomes less open due to an increase in home bias $(\kappa)$, the volatility of the real exchange rate also falls, for similar reasons. As the weight of domestically-produced traded goods rises from $10 \%$ to $90 \%$ of the traded goods basket, the volatility of the real exchange rate falls from 3.9 to 3 times the volatility of output. However, unlike with changes in $\gamma$, the variance decompositions exhibit an inverted-U shape centered at $\kappa=0.5$ because home bias has a non-monotonic effect on the volatility of $\mathrm{rer}^{N}$.

An increase in price stickiness $(\theta)$ reduces the effect of monetary shocks on the volatility of the real exchange rate. This may appear to be at odds with Dornbusch's (1976) overshooting effect, in which sticky prices magnify the response of the nominal and real exchange rates to monetary shocks. The difference is due to the alternative (but equivalent) ways of introducing monetary shocks in the model. In Dornbusch's model monetary shocks consist of changes in the money supply. If prices are sticky, changes in the money supply translate into changes in the interest rate. The stickier prices are, the higher is the response of the interest rate and the nominal exchange rate. However in this model monetary shocks are directly introduced as exogenous changes in the interest rate. A higher degree of price stickiness does not affect the size of the exogenous interest rate change. But the additional price stickiness reduces the response of prices to monetary shocks. The increase in price stickiness reduces the volatility of $\mathrm{rer}^{N}$ (which depends only on prices) faster than that of $\mathrm{rer}^{T}$ (which depends on prices but also on the more flexible nominal exchange rate). Therefore as prices become stickier the relative importance of $\operatorname{rer}^{N}$ falls.

As in the case of productivity shocks, a higher degree of risk aversion increases the volatility of the real exchange rate. In this case, when the coefficient of relative risk-aversion rises from one to five the volatility of the real exchange rate relative to output rises from 1.7 to 8.4. However in this case the increase in real exchange rate volatility is primarily due to an increase in the volatility of $\mathrm{rer}^{T}$.

\section{Summary and Conclusions}

This paper uses a two-country DSGE model to study how different characteristics of the economy affect the volatility of real exchange rate fluctuations and the fraction of those fluctuations that are caused by movements in the relative price of non-traded goods. The model shows that productivity shocks, whether sector-specific or economy-wide, cause real exchange rate movements mainly by changing the relative price between traded and non-traded goods. They also create significant deviations from purchasing power parity for traded goods prices. By contrast, monetary shocks are transmitted to the real exchange rate almost exclusively through changes in the international relative price of traded goods. This has important implications for economic modeling. A model meant to study the effects of productivity shocks on the real exchange rate cannot assume that all goods are tradable, since that would ignore a major channel through which productivity shocks affect the real exchange rate. On the other hand, the omission of non-traded goods in a model driven by monetary shocks may be less significant.

The model's impulse-response functions show that the response of the real exchange rate to productivity shocks depends on how the shock affects the relative price of non-traded goods. A positive productivity shock in the non-traded goods sector reduces the relative price of non-traded goods and causes a real depreciation, while a shock in the traded good sector raises the relative price of non-traded goods and causes a real appreciation. Productivity shocks also cause deviations from PPP for traded goods prices, but they can only partially offset the effect of the relative price of non-traded goods on the real exchange rate. In the case of monetary shocks the 
change in the real exchange rate depends on whether traded goods become more or less expensive at home than abroad. The change in the relative price of non-traded goods is quantitatively much less important.

The results from the model's simulation under different assumptions indicate that whether openness and global interdependence contribute to increase or decrease the volatility of the real exchange rate depends on the type of shock. In more open economies the real exchange rate exhibits smaller swings in response to productivity shocks but larger movements in response to monetary shocks. The reason is that, in general, as two economies become more integrated, the relative price of non-traded goods loses relative importance as the driver of real exchange rate fluctuations. Since monetary shocks are transmitted almost exclusively through PPP deviations for traded goods prices, they generate more volatility as that component gains relative importance.

A higher degree of price stickiness moderates the response of the real exchange rate to both types of shocks, as prices of traded and non-traded goods change more slowly. In the case of monetary shocks it also reduces the relative importance of the relative price of non-traded goods. In the case of productivity shocks the effect on the variance decompositions is not monotonic.

The real exchange rate is more volatile when countries exhibit a high degree of risk aversion. In the case of productivity shocks that increase in volatility is mostly attributed to movements in the relative price of non-traded goods. But in the case of monetary shocks it's attributed to deviations from PPP for traded goods prices.

Productivity shocks generate changes in the relative price between traded and non-traded goods even when they are not sector-specific. But a higher degree of correlation between sectorial shocks reduces those movements and causes a reduction in the volatility of the real exchange rate.

One interesting observation is that, since the two components of the real exchange rate are negatively correlated, it's possible that a factor that reduces the volatility of one or both components of the real exchange rate may actually contribute to increase the overall volatility of the real exchange rate. That's the case with an increase home bias: productivity shocks generate fewer movements in the relative price of non-traded goods and fewer PPP deviations for traded goods prices, yet the real exchange rate becomes more volatile because changes in the latter now offset fewer movements of the former.

Overall the study shows that real exchange rate variance decompositions are highly sensitive to the type of shock hitting the economy. That is important because empirical studies in which PPP deviations for traded goods prices seem to dominate real exchange rate movements may be interpreted as implying that changes in the relative price of non-traded goods are not important, even if they are very important for the transmission of productivity shocks. The level of real exchange rate volatility and its variance decomposition also depend on the characteristics of the economy. But whether those factors increase or reduce that volatility and the contribution of changes in the relative price of non-traded goods often depends on what type of shock is more prevalent.

\section{References}

Backus, D., Kehoe, P., \& Kydland, F. (1994). Dynamics of the Trade Balance and the Terms of Trade: The J-Curve? American Economic Review, 84(1), 84-103.

Backus, D., \& Smith, G. (1993). Consumption and Real Exchange Rates in Dynamic Economies with Non-Traded Goods. Journal of International Economics, 35(3-4), 297-316. http://dx.doi.org/10.1016/0022-1996(93)90021-O

Balassa, B. (1964). The Purchasing Power Parity Doctrine: A Reappraisal. Journal of Political Economy, 72(6), 584-596. http://dx.doi.org/10.1086/258965

Benigno, G., \& Thoenissen, C. (2008), Consumption and Real Exchange Rates with Incomplete Markets and Non-traded Goods. Journal of International Money and Finance, 27(6), 926-948. http://dx.doi.org/10.1016/j.jimonfin.2008.04.008

Betts, C., \& Kehoe, T. (2006). U.S. Real Exchange Rate Fluctuations and Relative Price Fluctuations. Journal of Monetary Economics, 53(7), 1297-1326. http://dx.doi.org/10.1016/j.jmoneco.2005.05.011

Burstein, A., Eichenbaum, M., \& Rebelo, S. (2006). The Importance of Nontradeable Goods' Prices in Cyclical Real Exchange Rate Fluctuations. Japan and the World Economy, 18(3), 247-253. http://dx.doi.org/10.1016/j.japwor.2006.02.003

Calvo, G. (1983). Staggered Prices in a Utility Maximizing Framework. Journal of Monetary Economics, 12(3), 383-398. http://dx.doi.org/10.1016/0304-3932(83)90060-0 
Chari, V., Kehoe, P., \& McGrattan, E. (2002). Can Sticky Price Models Generate Volatile and Persistent Real Exchange Rates? Review of Economic Studies, 69(3), 533-563. http://dx.doi.org/10.1111/1467-937X.00216

Corsetti, G., Dedola, L., \& Leduc, S. (2005). DGSE Models of High Exchange-Rate Volatility and Low Pass-Through. FRB International Finance Discussion Papers, 845.

Dornbusch, R. (1976). Expectations and Exchange Rate Dynamics. Journal of Political Economy, 84(6), 11611176. http://dx.doi.org/10.1086/260506

Engel, C. (1999). Accounting for U.S. Real Exchange Rate Changes. Journal of Political Economy, 107(3), 507538. http://dx.doi.org/10.1086/250070

Mendoza, E. (2000). On the Instability of Variance Decompositions of the Real Exchange Rate across Exchange Rate Regimes: Evidence from Mexico and the United States. NBER Working Paper 7768. http://dx.doi.org/10.3386/w7768

Mendoza, E. (2005). Real Exchange Rate Volatility and the Price of Nontradeable Goods in Economies Prone to Sudden Stops. Economia, 6(1), 103-148. http://dx.doi.org/10.1353/eco.2006.0008

Rogoff, K. (1996). The Purchasing Power Parity Puzzle. Journal of Economic Literature, 34(2), 647-668.

Samuelson, P. (1664). Theoretical Notes on Trade Problems. Review of Economics and Statistics, 46(2), $145-154$. http://dx.doi.org/10.2307/1928178

Stockman, A., \& Tesar, L. (1995). Tastes and Technology in a Two-Country Model of the Business Cycle: Explaining International Comovements. American Economic Review, 85(1), 168-185.

\section{Notes}

Note 1. This approach is used to explain the well-known relationship between productivity and real exchange rate rates known as the Balassa-Samuelson effect (Balassa (1964), Samuelson (1964)).

Note 2. For example, assuming that the overall price index is a geometric average of the price indices for both types of goods, $P=\left(P^{T}\right)^{(I-\gamma)} \times\left(P^{N}\right)^{\gamma}$, then $P / P^{T}=\left(P^{N} / P^{T}\right)^{\gamma}$, where $P^{N} / P^{T}$ is the domestic relative price between traded and non-traded goods and $\gamma$ is the weight of non-traded goods in the overall price index.

Note 3. Engel (1999) used the mean square error rather than the variance to take into account the trend.

Note 4. Among the countries that he studied the only exception was the U.S.-Canada exchange rate, for which the relative price of non-traded goods gained importance at longer horizons.

Note 5. The data used to calculate that ratio is in logarithms and detrended with the Hodrick-Prescott filter. The measure of real exchange rate used corresponds to the broad real effective real exchange rate provided by the Federal Reserve.

Note 6. The variance decomposition results from obtained from a log-linearized DSGE model are more directly comparable to results obtained using detrended data, but the empirical studies mentioned in the text do not detrend the real exchange rate. One exception is Betts and Kehoe (2006), but they only use detrended data to compute the variance decomposition in the case of annual deviations, not quarterly changes.

Note 7. The three models discussed earlier in this section do not include economy-wide, unbiased productivity shocks. The properties of the economy-wide productivity shock used in the impulse-response functions are constructed using weighted averages of the properties of the sector-specific productivity shocks.

Note 8 . Recall that the real exchange rate is defined as the cost of foreign goods in terms of domestic goods. Therefore a rise in the real exchange rate represents a depreciation and a fall represents an appreciation.

Note 9. Home bias creates an additional source of deviations from purchasing power parity for traded goods prices. Even if the law of one price is satisfied, meaning that goods produced in a country cost the same at home and abroad $\left(P^{H}=S \times P^{H^{*}}\right.$ and $\left.P^{F}=S \times P^{F^{*}}\right)$, under home bias differences between the prices of goods produced at home and abroad $\left(P^{H} \neq P^{F}\right)$ cause differences in the prices of the baskets of traded goods consumed in the Home and Foreign economies $\left(P^{T} \neq P^{T^{*}}\right)$. However this additional source of volatility is not quantitatively significant in this case. 


\section{Copyrights}

Copyright for this article is retained by the author(s), with first publication rights granted to the journal.

This is an open-access article distributed under the terms and conditions of the Creative Commons Attribution license (http://creativecommons.org/licenses/by/3.0/). 